\title{
Cerebral palsy in very low birthweight infants
}

\author{
R W I Cooke
}

\begin{abstract}
Eighty one very low birthweight survivors with cerebral palsy were matched with controls by sex, gestational age, and place of birth. Using discriminant analysis, the perinatal profiles for infants with cerebral palsy and their controls were shown to differ significantly. When infants with various types of cerebral palsy were analysed with their controls the discriminating variables differed. Diplegic infants could be differentiated from controls on antenatal variables alone, but significant discrimination of hemiplegic and quadriplegic infants required the addition of postnatal variables. Cranial ultrasound appearances differed appreciably between types of cerebral palsy. Future studies should differentiate between types of cerebral palsy and include ultrasound data. Cerebral palsy in very low birthweight infants is unlikely to prove a useful outcome indicator for neonatal intensive care.
\end{abstract}

Cerebral palsy has been defined as 'a group of disorders of movement and posture due to a defect or lesion of the immature brain' ${ }^{1}$ It is the most prevalent severe disability in very low birthweight survivors, and has been proposed as an outcome measure for neonatal intensive care. ${ }^{2}$ The assumption is that cerebral palsy is part of a continuum of causality from intrauterine death and growth retardation, through neonatal disease, to survival more or less intact, and that perinatal care may somehow modify this. Large scale studies have shown a much higher prevalence of cerebral palsy with shorter gestation, ${ }^{3}$ but there is a lack of evidence to suggest that the perinatal profiles of very low birthweight children with cerebral palsy differ significantly from those of infants without cerebral palsy. ${ }^{4}$ Doubt has been cast on the value of cerebral palsy as a method of audit of neonatal intensive care, even if perinatal brain injury is responsible for the cerebral palsy. Most such studies antedate the introduction of neonatal cranial ultrasound scanning, and so no direct evidence for perinatal brain lesions was available.

Recent publications show a strong link between cerebral palsy and ultrasound scan appearances in the neonatal period, ${ }^{5}$ suggesting that the problem may indeed relate to perinatal events in very low birthweight infants at least. Many large aetiological studies of cerebral palsy have included all birth weights together in analyses, and also have analysed all types of cerebral palsy together as if assuming that they have the same aetiologies. Such a study design may obscure possible associations if they apply only to one birthweight group or to only one type of cerebral palsy. Cerebral palsy is a collective diagnosis, and it has been suggested since the 19th century that the aetiology of diplegia and hemiplegia differed. ${ }^{6}$ More recently authors have re-emphasised the need to consider these conditions separately. This study aims to test the hypothesis that cerebral palsy in very low birthweight infants relates in the main to postnatal brain injury rather than antenatal factors, and that the aetiologies of cerebral palsy types differ.

\section{Patients and methods}

A prospective follow up of all very low birthweight infants admitted to the Mersey Regional Neonatal Intensive Care Unit has been made since January 1980 and is ongoing. All infants are frequently examined by cranial ultrasound during their hospital stay. Perinatal details, ultrasound appearances, and subsequent follow up details are stored on a database. The details of follow up and the classification of ultrasound appearances used have been published. ${ }^{5}$

Many different classifications of cerebral palsy have been proposed over the last century, and agreement on diagnosis between different clinicians is notoriously difficult to achieve. The great majority of infants in this study had spastic forms of cerebral palsy, although there were a small number of complex mixed and athetoid cases. The later were included in the total number of cases but not analysed separately. Spastic hemiplegia was defined as involvment of an arm and leg on the same side of the body, spastic diplegia as involvement of both legs more than the arms or involvement of the legs alone, and spastic quadriplegia (bilateral hemiplegia) as involvement of all four limbs similarly or with more severe involvement of the arms than legs. The functional abilities of the children varied greatly, but infants were only included if their impairment produced a noticeable disability. Children with a diagnosis of 'clumsiness' were not included. Much of the difficulty in classification of cerebral palsy relates to the 'evolving' presentation of the disorder as the child develops. More than half of the infants in this study have been followed up to five years or more, and all for at least two years.

All infants surviving to 2 years of age between 1980 and 1986 inclusive and with follow up diagnosis of cerebral palsy were selected. A control case was selected for each index case matched for gestational age, sex, and 
on whether the infant was a booked case, an in utero transfer, or a postnatal transfer to the unit. The reason for matching on this latter variable was that on a preliminary examination of the data, cerebral palsy was found to be twice as prevalent in survivors of in utero transfer and four times as prevalent in survivors of postnatal transfer as in those booked and born in the unit. Selection was made of the matching case with the nearest date of birth to that of the index case and, with the exception of five infants, this was within one year. Problems with matching very immature infants arose when more than one control was sought, and so the study was confined to one control per case rather than choose more controls from very different periods.

Details were abstracted from the ultrasound follow up database and the mothers' and infants' hospital records. Variables abstracted are listed in tables 1-6 and the appendix. They were chosen to describe the social class, health, and obstetric history of the mother, and problems in pregnancy, labour, delivery, and the neonatal period. Other variables described neurological and ultrasound abnormalities in the neonatal period and the outcome at between two and five years. These variables were compared in a univariate manner between all cerebral palsy index cases and matched controls, and then between hemiplegic, diplegic, and quadriplegic infants and their respective controls. The $\chi^{2}$ test, Fisher's exact test, or the Wilcoxon rank test was used as appropriate. Variables which differed significantly between index cases and controls with a probability of $\mathrm{p}<0.2$ were selected and used as independent variables in separate discriminant analyses with all cases of cerebral palsy, hemiplegia, diplegia,

Table 1 Univariate analysis of variables by cerebral palsy and controls, and by hemiplegia, diplegia, and quadriplegia and controls: maternal variables

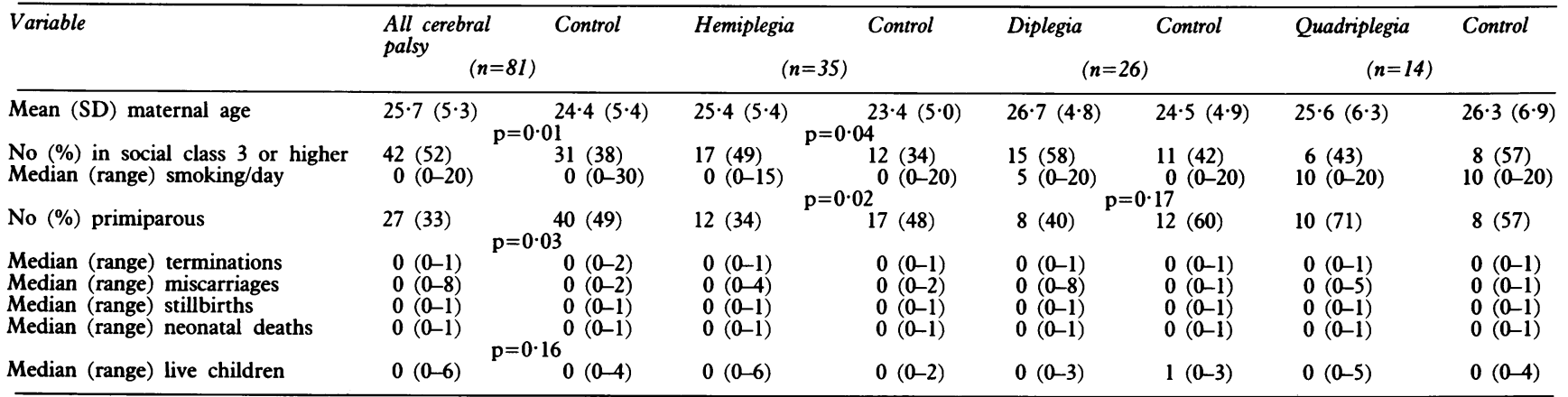

Differences significant at $\mathrm{p}<0.2$ are shown.

Table 2 Univariate analysis of variables by cerebral palsy and controls, and by hemiplegia, diplegia, and quadriplegia and controls: pregnancy variables (results are number (\%) unless otherwise stated)

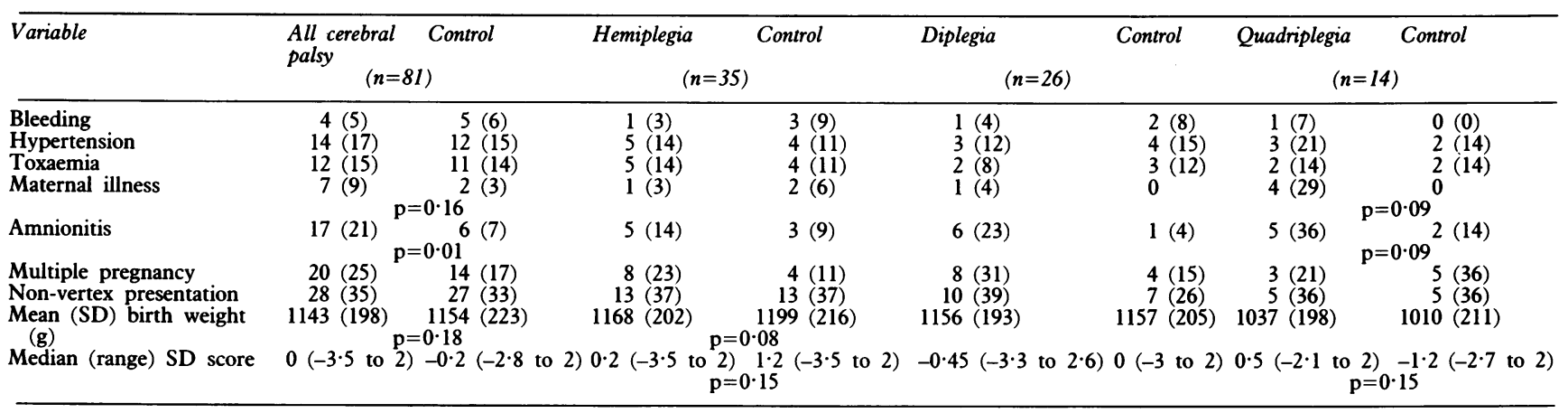

Differences significant at $\mathrm{p}<0 \cdot 2$ are shown.

Table 3 Univariate analysis of variables by cerebral palsy and controls, and by hemiplegia, diplegia, and quadriplegia and controls: labour and delivery variables (results are number (\%) unless otherwise stated)

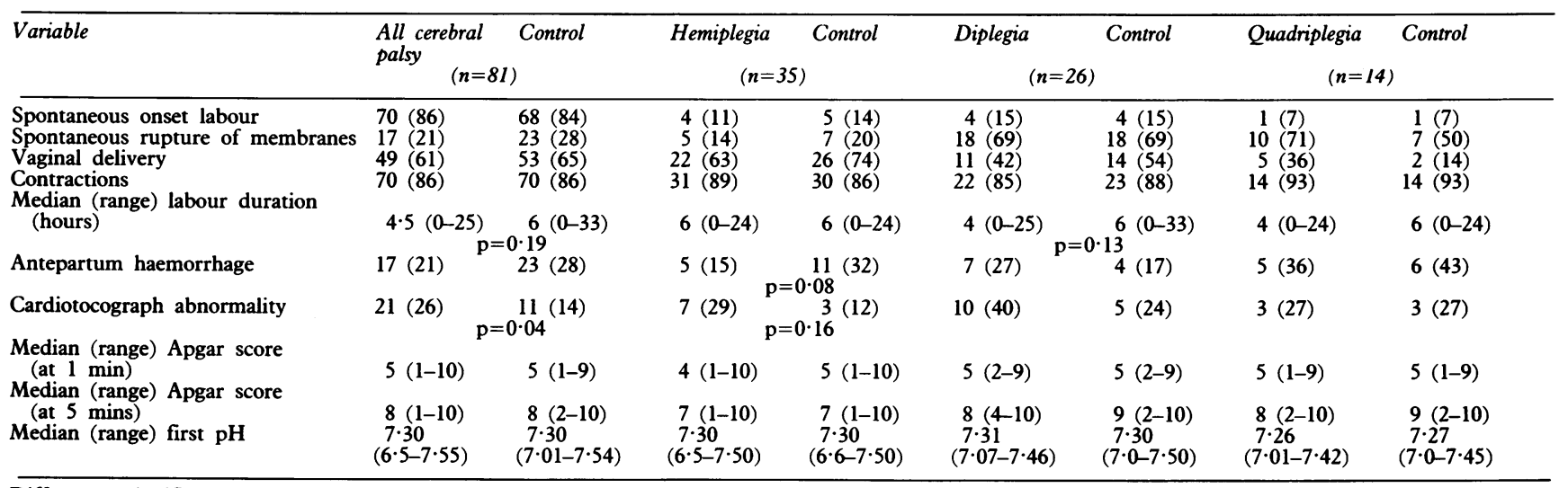


Table 4 Univariate analysis of variables by cerebral palsy and controls, and by hemiplegia, diplegia, and quadriplegia and controls: neonatal variables (results are number (\%) unless otherwise stated)

\begin{tabular}{|c|c|c|c|c|c|c|c|c|}
\hline Variable & $\begin{array}{l}\text { All cerebrc } \\
\text { palsy }\end{array}$ & Control & $\begin{array}{r}\text { Hemiplegia } \\
(n=3\end{array}$ & Control & $\begin{array}{r}\text { Diplegia } \\
(n=\end{array}$ & $\begin{array}{l}\text { Control } \\
=26)\end{array}$ & $\begin{array}{r}\text { Quadriplegic } \\
(n=\end{array}$ & Control \\
\hline Hyaline membrane disease & $59(73)$ & $45(56)$ & $28(80)$ & $20(57)$ & $17(65)$ & $11(42)$ & $10(71)$ & $11(79)$ \\
\hline Pneumothorax & $19(24)$ & $11(14)$ & $8(23)$ & $\begin{array}{r}3 \\
3 \\
18\end{array}$ & $5(19)$ & $\begin{array}{r}p=009(15) \\
4\end{array}$ & $4(29)$ & $2(14)$ \\
\hline Median (range) ventilator days & \multicolumn{2}{|c|}{$p=0.00007$} & \multicolumn{2}{|c|}{$\mathrm{p}=0.008$} & \multirow{2}{*}{\multicolumn{2}{|c|}{$4(15) \quad p=0.07$}} & \multirow{2}{*}{\multicolumn{2}{|c|}{$7(50) \quad p=0.02$}} \\
\hline Bronchopulmonary dysplasia & $24(29)$ & $12(15)$ & $10(29)$ & $6(17)$ & & & & \\
\hline Necrotising enterocolitis & $13(16)$ & 0.02 & $4(11)$ & $3(9)$ & $3(11)$ & $1(4)$ & $5(36)$ & \\
\hline Septicaemia & $33(41)$ & $\begin{array}{c}19(24) \\
0 \cdot 01\end{array}$ & $17(49)$ & $8(23)$ & $7(27)$ & $4(15)$ & \multicolumn{2}{|c|}{$\mathrm{p}=0.04$} \\
\hline Hyperbilirubinaemia & $22(27)$ & $15(19)$ & $7(20)$ & $8(23)$ & $10(39)$ & $p=0 \cdot 11^{4(15)}$ & $4(29)$ & $3(21)$ \\
\hline
\end{tabular}

Differences significant at $\mathrm{p}<0 \cdot 2$ are shown.

Table 5 Univariate analysis of variables by cerebral palsy and controls, and by hemiplegia, diplegia, and quadriplegia and controls: neurological variables (results are number (\%))

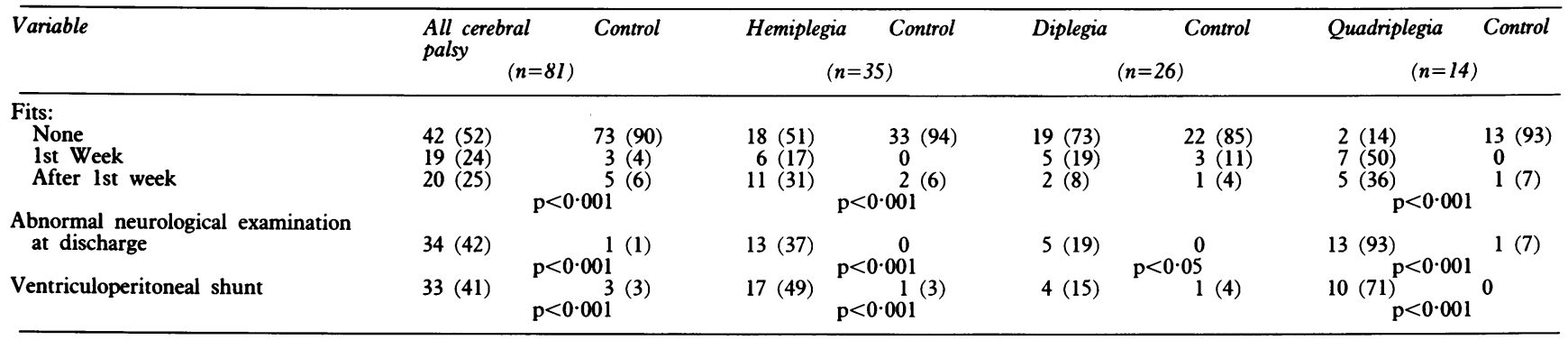

Differences significant at $\mathrm{p}<0 \cdot 2$ are shown.

Table 6 Univariate analysis of variables by cerebral palsy and controls, and by hemiplegia, diplegia, and quadriplegia and controls: ultrasound variables (results are number (\%))

\begin{tabular}{|c|c|c|c|c|c|c|c|c|}
\hline Variable & $\begin{array}{l}\text { All cereb } \\
\text { palsy }\end{array}$ & Control & $\begin{array}{r}\text { Hemiplegia } \\
\qquad n=\end{array}$ & Control & Diplegia & Control & $\begin{array}{r}\text { Quadriplegia } \\
\qquad(n=14\end{array}$ & Control \\
\hline $\begin{array}{l}\text { Early ultrasound: } \\
\text { Normal } \\
\text { 'Flare' } \\
\text { Subependymal haemorrhage } \\
\text { Intraventricular haemorrhage } \\
\text { Parenchymal haemorrhage }\end{array}$ & $\begin{aligned} 17 & (21) \\
1 & (1) \\
9 & (11) \\
23 & (28) \\
31 & (38)\end{aligned}$ & $\begin{aligned} 43 & (53) \\
2 & (2) \\
21 & (26) \\
15 & (19) \\
0 & \\
001 & \end{aligned}$ & $\begin{aligned} & 4(11) \\
0 & \\
3 & (9) \\
6 & (17) \\
22 & (63)\end{aligned}$ & $\begin{aligned} & 18(51) \\
& 2(6) \\
& 9(26) \\
& 6(17) \\
& 0 \\
& 001\end{aligned}$ & $\begin{aligned} 11 & (42) \\
1 & (4) \\
4 & (15) \\
7 & (27) \\
3 & (12)\end{aligned}$ & $\begin{array}{r}17(65) \\
0 \\
7(27) \\
2(8) \\
0 \\
06\end{array}$ & $\begin{array}{l}1(7) \\
0 \\
0 \\
7(50) \\
6 \underset{6}{(43)} \quad \\
\quad p=0.0\end{array}$ & $\begin{array}{l}4(29) \\
0 \\
4(29) \\
6(43) \\
0\end{array}$ \\
\hline $\begin{array}{l}\text { Late ultrasound: } \\
\text { Normal } \\
\text { 'Flare' } \\
\text { Persistent ventricular enlargement } \\
\text { Periventricular leucomalacia } \\
\text { Porencephalic cyst }\end{array}$ & $\begin{aligned} & 21(26) \\
& 1(1) \\
& 10(12) \\
& 13(16) \\
& 36(44)\end{aligned}$ & $\begin{array}{l}73(90) \\
0 \\
5(6) \\
3(4) \\
0 \\
001\end{array}$ & $\begin{aligned} & 5(14) \\
& 0 \\
& 4(11) \\
& 3(9) \\
& 23(66)\end{aligned}$ & $\begin{array}{c}32(91) \\
3(9) \\
0 \\
0 \\
0 \\
001\end{array}$ & $\begin{aligned} 14 & (54) \\
1 & (4) \\
5 & (19) \\
3 & (12) \\
3 & (12)\end{aligned}$ & $\begin{array}{c}25(96) \\
0 \\
0 \\
1 \\
0 \\
01\end{array}$ & $\begin{array}{l}0 \\
0 \\
0 \\
4(29) \\
10(72) \\
\quad \mathrm{p}<0.0\end{array}$ & $\begin{aligned} & 11(79) \\
& 0 \\
& 1 \\
& 2(7) \\
& 0\end{aligned}$ \\
\hline $\begin{array}{l}\text { None } \\
\text { Unilateral } \\
\text { Bilateral }\end{array}$ & $\begin{array}{l}32(40) \\
24(30) \\
25(31)\end{array}$ & $\begin{aligned} 78 & (96) \\
2 & (3) \\
1 & (1) \\
001 & \end{aligned}$ & $\begin{aligned} & 10(29) \\
& 18(51) \\
& 7(20)\end{aligned}$ & $\begin{array}{c}35 \\
0 \\
0 \\
001\end{array}$ & $\begin{aligned} 19 & (73) \\
2 & (8) \\
5 & (19)\end{aligned}$ & $\begin{array}{r}25(96) \\
1(4) \\
0 \\
04\end{array}$ & $\begin{array}{l}0 \\
3(21) \\
11(79) \\
\quad p<0.0\end{array}$ & $\begin{aligned} 12 & (86) \\
1 & (7) \\
1 & (7)\end{aligned}$ \\
\hline
\end{tabular}

Differences significant at $\mathrm{p}<0 \cdot 2$ are shown.

or quadriplegia and their controls as the dependent variable. The programme 'Discriminant' from SPSS-X was used. ${ }^{7}$ This programme uses stepwise linear regression to produce a discriminant model. Linear combinations of variables are used to distinguish between two or more categories of cases, in this instance, cases of cerebral palsy and their controls. The variables discriminate between the cases and controls and predict into which category a case or control falls based on the values of these variables. To find the linear combination of variables that best discriminates between cases and controls, stepwise methods are used to find a set of variables that maximise discriminating power as defined by various criteria. Variables are included in the analysis in order of their signifi- cance, and the model tested for its significance in discriminating between infants with cerebral palsy and their controls. Variables are removed from the model when the addition of subsequent variables reduces the significance of their discriminant power. The level of significance of any variable required to enter the analysis was set as that associated with a value of ' $F$ ' greater than 1 , and to remove a variable, ' $F$ ' less than 1 . The final model is then tested by using it to assign cases to the two groups, that is, cerebral palsy and controls, and the percentage correct predictions given. The significance of the model and the residual variance (variance not explained by the model) is also shown.

For each cerebral palsy group discriminant analyses were performed for variables relating 
Table 7 Discriminant analysis of variables by cerebral palsy and controls, and hemiplegia, diplegia, and quadriplegia and controls. Variables are grouped as (a) those relating to the period up until birth, $(b)$ then including neonatal clinical variables, $(c)$ then including neurological variables, and $(d)$ then including ultrasound variables. Residual variance, significance, and percentage correctly predicted cases are shown for each analysis. Variables shown are those remaining in the discriminant model at the end of each stepwise analysis, and are in order of their importance in the model

\begin{tabular}{|c|c|c|c|c|}
\hline Variable group & All cerebral palsy $(n=81)$ & Hemiplegia $(n=35)$ & Diplegia $(n=26)$ & Quadriplegia $(n=14)$ \\
\hline $\begin{array}{l}\text { (a) Maternal, pregnancy, } \\
\text { labour, and delivery }\end{array}$ & $\begin{array}{l}\text { Amnioitis, parity, maternal } \\
\text { illness, labour, cardiotoco- } \\
\text { graphy }\end{array}$ & $\begin{array}{l}\text { Maternal age, cardiotoco- } \\
\text { graphy, smoking }\end{array}$ & $\begin{array}{l}\text { Labour, amnionitis, Apgar 5, } \\
\text { smoking }\end{array}$ & Maternal illness, SD score \\
\hline $\begin{array}{l}\text { Residual variance } \\
\text { Predicts (\%) } \\
\text { Significance }\end{array}$ & $\begin{array}{l}0 \cdot 87 \\
62 \\
p=0.002\end{array}$ & $\begin{array}{l}0.93 \\
64 \\
p=0 \cdot 19\end{array}$ & $\begin{array}{l}0 \cdot 71 \\
77 \\
p=0 \cdot 002\end{array}$ & $\begin{array}{l}0 \cdot 80 \\
64 \\
p=0.58\end{array}$ \\
\hline $\begin{array}{l}\text { (b) Maternal, pregnancy, } \\
\text { labour, delivery, and } \\
\text { neonatal }\end{array}$ & $\begin{array}{l}\text { Parity, necrotising enteroco- } \\
\text { litis, amnionitis, hyaline } \\
\text { membrane disease, neonatal } \\
\text { death, septicaemia, bron- } \\
\text { chopulmonary dysplasia, } \\
\text { labour, cardiotocography, } \\
\text { maternal illness }\end{array}$ & $\begin{array}{l}\text { Septicaemia, hyaline } \\
\text { membrane disease, } \\
\text { maternal age, } \\
\text { pneumothorax, SD score, } \\
\text { cardiotocography, } \\
\text { smoking }\end{array}$ & $\begin{array}{l}\text { Labour, amnionitis, hyaline } \\
\text { membrane disease, } \\
\text { smoking, Apgar 5, } \\
\text { hyperbilirubinaemia }\end{array}$ & $\begin{array}{l}\text { Necrotising enterocolitis, } \\
\text { maternal illness, ventilator } \\
\text { days }\end{array}$ \\
\hline $\begin{array}{l}\text { Residual variance } \\
\text { Predicts (\%) } \\
\text { Significance }\end{array}$ & $\begin{array}{l}0.79 \\
66 \\
p=0.0001\end{array}$ & $\begin{array}{l}0.80 \\
71 \\
p=0.04\end{array}$ & $\begin{array}{l}0.64 \\
81 \\
p=0.002\end{array}$ & $\begin{array}{l}0.64 \\
78 \\
p=0.024\end{array}$ \\
\hline $\begin{array}{l}\text { (c) Maternal, pregnancy, } \\
\text { labour, delivery, neonatal, } \\
\text { and neurological }\end{array}$ & $\begin{array}{l}\text { Neurology, shunt, labour, } \\
\text { parity, cardiotocography, } \\
\text { hyperbilirubinaemia, fits, } \\
\text { amnionitis necrotising } \\
\text { enterocolitis }\end{array}$ & $\begin{array}{l}\text { Shunt, neurology, pneumo- } \\
\text { thorax, maternal age, SD } \\
\text { score, septicaemia }\end{array}$ & $\begin{array}{l}\text { Labour, neurology, Apgar 5, } \\
\text { smoking, hyperbiliru- } \\
\text { binaemia }\end{array}$ & $\begin{array}{l}\text { Neurology, shunt, necrotising } \\
\text { enterocolitis }\end{array}$ \\
\hline $\begin{array}{l}\text { Residual variance } \\
\text { Predicts (\%) } \\
\text { Significance }\end{array}$ & $\begin{array}{l}0.63 \\
75 \\
p<0.0001\end{array}$ & $\begin{array}{l}0.59 \\
86 \\
p<0.0001\end{array}$ & $\begin{array}{l}0.64 \\
79 \\
p=0.0007\end{array}$ & $\begin{array}{l}0.21 \\
93 \\
p<0.0001\end{array}$ \\
\hline $\begin{array}{l}\text { (d) Maternal, pregnancy, } \\
\text { labour, delivery, } \\
\text { neonatal, neurological, } \\
\text { and ultrasound }\end{array}$ & $\begin{array}{l}\text { Late ultrasound, amnionitis, } \\
\text { labour, neonatal death, } \\
\text { neurology, birth weight, } \\
\text { parity }\end{array}$ & $\begin{array}{l}\text { Late ultrasound, neurology, } \\
\text { shunt, fits }\end{array}$ & $\begin{array}{l}\text { Late ultrasound, labour, } \\
\text { amnionitis, Apgar 5, } \\
\text { smoking }\end{array}$ & $\begin{array}{l}\text { Late ultrasound, shunt, } \\
\text { necrotising enterocolitis, } \\
\text { bilateral ultrasound }\end{array}$ \\
\hline $\begin{array}{l}\text { Residual variance } \\
\text { Predicts (\%) } \\
\text { Significance }\end{array}$ & $\begin{array}{l}0 \cdot 48 \\
83 \\
p<0 \cdot 0001\end{array}$ & $\begin{array}{l}0.30 \\
86 \\
p<0.0001\end{array}$ & $\begin{array}{l}0.55 \\
77 \\
\mathrm{p}<0.001\end{array}$ & $\begin{array}{l}0.15 \\
96 \\
\mathrm{p}<0.0001\end{array}$ \\
\hline
\end{tabular}

to the period up to the time of birth, then including postnatal clinical variables, neurological variables, and finally ultrasound data. Table 7 shows the variables selected and remaining in each analysis in order of their discriminant power, the residual variance, the percentage of cases correctly predicted, and the significance of the model.

\section{Results}

During the seven year period, 1142 very low birthweight infants were admitted. Of these, $761(67 \%)$ survived to at least 2 years of age. Eighty one of these survivors were identified on follow up as having cerebral palsy. Thirty five had a hemiplegia, 26 a diplegia, 14 bilateral hemiplegia (assymetrical quadriplegia), one a mild symmetrical quadriplegia, and five hypotonic or athetoid cerebral palsy.

A number of clinical and ultrasound variables differed significantly between all cases of cerebral palsy and controls on univariate analysis (tables 1-6). The significant differences between cases and controls varied according to the type of cerebral palsy examined. When significant variables for all cases and controls were entered in a stepwise discriminant analyses, $83 \%$ of subjects could be correctly assigned with a residual variance of 0.48 (table 7). Most of the discriminatory power was due to ultrasound findings, in particular the late appearances. If ultrasound data was then excluded from the analysis, $75 \%$ of subjects could be correctly assigned, with most of the power due to the 'neurology at discharge' variable. If all variables not directly related to cerebral ultrasound or neurological function were excluded, only $66 \%$ could be correctly assigned, and this fell to $62 \%$ if only variables recorded up to the time of delivery are considered.

When the discriminant analyses for the three main diagnosis groups are examined, while significant models for all diagnoses were produced, the variables selected differed considerably. The diplegic infants differed significantly from their controls on antenatal variables alone. Adding postnatal, neurological, and then ultrasound variables did not improve the discriminant power of the model, although residual variance and significance did improve. The variables selected were descriptive of a high risk mother (preterm labour, amnionitis, smoking) and of an immature infant (low 5 minute Apgar score, hyaline membrane disease, and hyperbilirubinaemia). Late ultrasound appearances were likely to be normal or minor abnormalities, and neonatal fits did not occur.

In neither hemiplegic nor quadriplegic infants was a significant model based on antenatal variables alone obtained. Adding postnatal variables to both groups produced significant models, which became more discriminant as neurology and ultrasound variables were added as well. Clinical variables selected for the hemiplegic group described an older mother with an at risk fetus (abnormality on cardiotocography and growth retardation) and an infant with serious illnesses (hyaline membrane disease, pneumothorax, ventriculoperitoneal shunt, fits, septicaemia). Severe late ultrasound changes were seen. A similar picture was seen in the quadriplegic group of a small infant with an ill mother and a chronic neonatal course (prolonged ventilation, necrotising enterocolitis, and ventriculoperitoneal shunt) and severe and often bilateral changes seen on ultrasound.

Table 6 compares the ultrasound changes 
seen in each diagnosis group and matched control group during the first week of life, and later in the neonatal period.

\section{Discussion}

Although Little's hypothesis that cerebral palsy was related to perinatal events has held support for 150 years, many more recent authors have suggested that earlier developmental events, even if not causative, may increase the fetal sensitivity to perinatal insults. In the last century Freud summarised this: 'Difficult birth is merely a symptom of deeper effects that influenced the development of the fetus' ${ }^{6}$ The excess of intrauterine growth retardation seen in infants at term with cerebral palsy would tend to support this concept. ${ }^{8}$ While two thirds of cerebral palsy occurs in term infants, the birth prevalence of cerebral palsy in the preterm infant is much higher, especially with diplegia; and appears to be rising in recent years. ${ }^{9}$ Freud also recognised that 'there is a specific relationship between premature birth and diplegic rigidity and difficult birth and general rigidity'. Paneth and Stark more recently suggest that 'determinants of CP [cerebral palsy] in LBW [low birthweight] infants differ from those in term infants and in particular are less closely related to birth asphyxia than they are to phenomena such as IVH [intraventricular haemorrhage]'. ${ }^{10}$ Stanley and English, however, found that 'the majority of LBW ( $<2000 \mathrm{~g}) \mathrm{CP}$ children had perinatal profiles which are no different from LBW children without CP'), and that 'IVH does not account for the majority of cases of CP in LBW infants'. ${ }^{4}$ Both studies antedate in vivo brain imaging. This study shows firstly the strong discriminant power of cerebral ultrasound examination in the neonatal period for later cerebral palsy, especially spastic hemiplegia and quadriplegia. Abnormal neurological examination at discharge and neonatal convulsions are also discriminant. This says nothing about antecedent variables, causative or contributary, but does imply that, as the abnormal ultrasound appearances are in the main not present at birth, but develop in the first few days to weeks of life, that they and the subsequently observed cerebral palsy are related to insults occurring at or after birth. The differences in ultrasound appearances noted in diplegic, hemiplegic, and quadriplegic cases of cerebral palsy suggest that the site and nature of the causative pathological lesion differs, as might be expected from their different neurological signs.

The perinatal profiles of very low birthweight infants with cerebral palsy differ significantly from controls in this study, but more obviously when different types of cerebral palsy are examined. Unlike the hemiplegic and quadriplegic infants, the diplegics could be differentiated from controls on antenatal variables alone and no improvement in the model occurred on adding postnatal variables. This would seem to show that diplegia is largely determined before birth, and relates to a high risk mother with an immature infant. On the other hand the variables that can discriminate between hemiplegic and quadriplegic infants and their controls are operative in the immediate postnatal period, and relate to severity of neonatal diseases, their complications, and resulting ultrasound detectable cerebral lesions. The severer course of quadriplegic infants and their more extensive and frequently bilateral ultrasound lesions seem to place quadriplegics at the extreme end of the clinical range of hemiplegia.

Future epidemiological studies of cerebral palsy in very low birthweight infants should differentiate between the types of the disorder, and include data on neonatal cranial ultrasound examinations. It is unlikely that the prevalence of cerebral palsy in very low birthweight survivors will provide a useful outcome measure for neonatal intensive care.

\begin{tabular}{|c|c|}
\hline \multicolumn{2}{|c|}{$\begin{array}{l}\text { Appendix } \\
\text { Variables used in the discriminant analyses }\end{array}$} \\
\hline Maternal age & Years \\
\hline Occupation & $\begin{array}{l}\text { Registrar General's classification (I-III } \\
\text { and IV, V and unemployed/ } \\
\text { unsupported) }\end{array}$ \\
\hline Smoking & Number cigarettes smoked \\
\hline Parity & Primiparous, multiparous \\
\hline Terminations & Number \\
\hline $\begin{array}{l}\text { Miscarriages } \\
\text { Stillbirths }\end{array}$ & $\begin{array}{l}\text { Number } \\
\text { Number }\end{array}$ \\
\hline Neonatal deaths & Number \\
\hline Live children & $\begin{array}{l}\text { Number } \\
\text { Yes/no any bleeding during pregnancy }\end{array}$ \\
\hline $\begin{array}{l}\text { Bleeding } \\
\text { Hypertension }\end{array}$ & $\begin{array}{l}\text { Yes/no, any bleeding during pregnancy } \\
\text { Yes/no, any hypertension receiving } \\
\text { treatment }\end{array}$ \\
\hline Toxaemia & Yes $/$ no, receiving treatment \\
\hline Maternal illness & $\begin{array}{l}\text { Yes/no, diabetes mellitus, renal failure, } \\
\text { thyroid disease }\end{array}$ \\
\hline Amnionitis & $\begin{array}{l}\text { Yes/no, premature rupture of } \\
\text { membranes with clinical signs of } \\
\text { infection }\end{array}$ \\
\hline Multiple pregnancy & Yes/no \\
\hline Presentation & Non-vertex, yes/no \\
\hline Birth weight & Grams \\
\hline $\begin{array}{l}\text { Standard deviation } \\
\text { (SD) score }\end{array}$ & $\begin{array}{l}\text { SD score, number of } S D \text { birth weight } \\
\text { above or below mean for gestational } \\
\text { age }\end{array}$ \\
\hline Spontaneous onset & \\
\hline $\begin{array}{l}\text { (labour) } \\
\text { Spontaneous rupture }\end{array}$ & Yes/no \\
\hline of membranes & Yes/no \\
\hline $\begin{array}{l}\text { Vaginal delivery } \\
\text { Contractions }\end{array}$ & $\begin{array}{l}\text { Yes/no } \\
\text { Yes/no, any uterine contractions before } \\
\text { delivery }\end{array}$ \\
\hline Labou & Duration in hours \\
\hline $\begin{array}{l}\text { Antepartum } \\
\text { haemorrhage }\end{array}$ & $\begin{array}{l}\text { Yes/no, whether due to placenta praevia } \\
\text { or abruption }\end{array}$ \\
\hline Cardiotocography & $\begin{array}{l}\text { Yes/no, presence of significant } \\
\text { abnormalities before or during labour }\end{array}$ \\
\hline $\begin{array}{l}\text { Apgar } 1 \\
\text { Apgar } 5\end{array}$ & $\begin{array}{l}\text { Score at one minute } \\
\text { Score at five minutes }\end{array}$ \\
\hline First pH & $\begin{array}{l}\text { First pH measured after birth (usually } \\
\text { cord } \mathrm{pH} \text { ) }\end{array}$ \\
\hline $\begin{array}{l}\text { Hyaline membrane } \\
\text { disease }\end{array}$ & Yes/no, diagnosis by radiography \\
\hline $\begin{array}{l}\text { Pneumothorax } \\
\text { Days on ventilator } \\
\text { Bronchopulmonary }\end{array}$ & $\begin{array}{l}\text { Yes/no, during first four days } \\
\text { Number }\end{array}$ \\
\hline dysplasia & Yes/no, in oxygen at 28 days \\
\hline $\begin{array}{l}\text { Necrotising } \\
\text { enterocolitis }\end{array}$ & Yes/no, radiography or surgical evidence \\
\hline Septicaemia & $\begin{array}{l}\text { Yes/no, positive blood culture in } \\
\text { neonatal period }\end{array}$ \\
\hline Hyperbilirubinaemia & $\begin{array}{l}\text { Yes/no, Serum bilirubin concentration } \\
>240 \mu \mathrm{mol} / 1\end{array}$ \\
\hline $\begin{array}{l}\text { Early ultrasound } \\
\text { Late ultrasound }\end{array}$ & $\begin{array}{l}\text { Classified as in Cooke } \\
\text { Classified as in Cooke }\end{array}$ \\
\hline Bilateral ultrasound & $\begin{array}{l}\text { None/unilateral/bilateral, presence of } \\
\text { parenchymal brain lesions on cranial } \\
\text { ultrasound }\end{array}$ \\
\hline Fits & $\begin{array}{l}\text { None, first week, after first week of life } \\
\text { but in newborn period }\end{array}$ \\
\hline Neurology & $\begin{array}{l}\text { Yes/no, abnormal neurological } \\
\text { examination at discharge. Performed } \\
\text { by residents, but not standardised. } \\
\text { Mainly comments on abnormalities of } \\
\text { tone, reflexes and visual attentiveness }\end{array}$ \\
\hline Shunt & $\begin{array}{l}\text { Yes/no, presence of ventriculoperitoneal } \\
\text { shunt }\end{array}$ \\
\hline
\end{tabular}


1 Bax M. Terminology and classification of cerebral palsy. Dev Med Child Neurol 1964;6:295-7.

2 Kiely JL, Paneth N, Stein Z, Susser M. Cerebral palsy and newborn care. 2: Mortality and neurological impairment in low birthweight infants. Dev Med Child Neurol 1981;23:650-9.

3 Powell TG, Pharoah POD, Cooke RWI. Survival and morbidity in a geographically defined population of low birthweight infants. Lancet 1986; : $: 539-43$.

4 Stanley FJ, English DR. Prevalence of and risk factors for cerebral palsy in a total population cohort of cerebral palsy in a total population cohort of lowbirthweight $(<2000 \mathrm{~g})$ infants. Dev Med Child Neurol $86 ; 28: 559-68$

Cooke RWI. Early and late cranial ultrasonographic appearances and outcome in very low birthweight infants. Arch Dis Child 1987;62:931-7.
6 Freud S. Die Infantile Cerebrallahmung. Wein: A Holder, 1897.

7 SSPS-Incorporated. Discriminant. SPSS- $X$ users guide. New York: McGraw-Hill, 1983:623-45.

8 Pharoah POD, Cooke T, Rosenbloom L, Cooke RWI Effects of birthweight, gestational age, and materna obstetric history on birth prevalence of cerebral palsy. Arch Dis Child 1987;62:1035-40.

9 Pharoah POD, Cooke T, Rosenbloom L, Cooke RWI Trends in birth prevalence of cerebral palsy. Arch Dis Child 1987;62:379-84.

10 Paneth N, Stark RI. Cerebral palsy and mental retardation in relation to indicators of perinatal asphyxia. Am $\mathcal{J}$ Obstet Gynecol $1983 ; 147: 960-6$. 